\title{
LIVONIAN LANDSCAPES IN THE HISTORICAL GEOGRAPHY OF LIVONIA AND THE DIVISION OF THE LIVONIAN TRIBES
}

\author{
Urmas Sutrop \\ Institute of the Estonian Language, Tallinn, \\ and the University of Tartu
}

\begin{abstract}
There is no exact consensus on the division and sub-division of the former Livonian territories at the end of the ancient independence period in the 12th century. Even the question of the Coastal Livonians in Courland - were they an indigenous Livonian tribe or a replaced eastern Livonian tribe - remains unsolved. In this paper the anonymously published treatise on the historical geography of Livonia by Johann Christoph Schwartz (1792) will be analysed and compared with the historical modern views. There is an agreement on the division of the Eastern Livonian territories into four counties: Daugava, Gauja, Metsepole, and Idumea. Idumea had a mixed Livonian-Baltic population. There is no consensus on the parochial sub-division of these counties.
\end{abstract}

Keywords: Johann Christoph Schwartz, historical geography, Livonian tribes, Livonians

DOI: http://dx.doi.org/10.12697/jeful.2014.5.1.02

\section{Introduction}

It is commonly believed that Livonians (like Estonians) did not form either territorial or political unity at the end of the ancient independence period in the 12th century (see e.g. Koski 1997: 45). The first longer document where Livonians are described is the Livonian Chronicle (Heinrici Cronicon Lyvoniae) for the period 1180 to 1227 written by Henry of Livonia, an eyewitness of these events.

Modern ideas on the division of Eastern Livonian peoples and territories go back to the cartographic work of Heinrich Laakmann, who divided Livonians into three territories - Daugava, Thoreida, and Metsepole; and added that there was a mixed Livonian-Baltic population at the end of the 12th century in Idumea (see the map Baltic Lands: population about $1200 \mathrm{AD}$ and explanation to this map in Laakmann 1954). Laakmann thought that there were no Livonians in Courland at that time. 
Mauno Koski found that the following Livonian territories are mentioned in the Chronicle. First, the territory of Daugava Livonians (Veinalenses) was the most southern; it extended from the mouth of Daugava to $100 \mathrm{~km}$ upstream to Aizkraukle. Second, north of the Daugava Livonians there was the territory of Gauja Livonians; it stretches from the seashore up to $50 \mathrm{~km}$ into hinterland; its main centre was in Toreida. The territory of the Daugava Livoninas had four sub-divisions: Toreida, Sattesele (Suntaži, Sunzel), Lēdurga, and Kubbesele. Sometimes the name Toreida Livonians designated all Gauja Livonians or at least Toreida and Kubbesele Livonians. Koski argued that it is not possible to decide whether Gauja Livonians formed one territory or two or three. Third, north of the Gauja Livoninas there was Metsepole County. ${ }^{1}$ Koski was not sure whether Metsepole Livonians belonged to Livonia proper. As his task was to describe the Livonian territory (Liefland), Koski does not include Curonian Livonians in his discussion (1997: 45). Fourth, he argued that there was a mixed population of Latvians and some Finnic tribes, maybe Livonians, in Idumea (Koski 1997: 46). At the same time, the question of the territorial and tribal structure of the Livonian people is not in the research focus. For example, in a recent atlas of the history of Latvia the Livonians are divided into three groups - Curonian, Daugava, and Gauja Livoninas - without any border between them, except Idumea which is marked with mixed Livonian and Latgallian population, at the end of the 12th century. On the same map other Latvian counties are subdivided in detail (see map in Turlajs 2012: 12). Ẽvalds Mugurēvičs divided Eastern Livonians into four groups: Daugava, Toreidian, Metsepole, and Idumea (Mugurevič 1965: 1920).

The territorial distribution of the Livonian tribes at the end of the ancient independence period in the 12th century is not fully explained yet. Hence the intriguing question - how many different Livonian tribes and territories were there at that time? In an earlier paper I examined Heinrich von Jannau's (1828) division of the territory inhabited by the Livonians. He divided the territory into nine districts following the division of Old Livonia published anonymously in Hupel's Neue Nordische Miscellaneen (see Sutrop 2009). According to the Digital Text Repository for Older Estonian Literature EEVA the anonymous author was Johann Christoph Schwartz. ${ }^{2}$

\footnotetext{
For the Metsepole County see Sutrop and Pajusalu (2009) and Sutrops (2013).

2 Johann Christoph Schwartz (Schwarz) (1722-1804), Baltic-German legal scholar and historian, the mayor of Riga. See online at

$<$ http://www.utlib.ee/ekollekt/eeva/index.php?lang=en\&do=autor\&aid=680>.

Accessed on 16.01.2014.
} 
In this paper I will take a closer look at the anonymously published treatise on the historical geography of Livonia (Schwartz, sine nomine, 1792).

\section{Historical geography of Livonia in 1792}

Johann Christoph Schwartz wrote in his treatise on the historical geography of Livonia that the Livonian Province of the Teutonic Order had no common name at the time when Germans arrived in these lands (1792: 17). At the time when this country was discovered by Germans, he continued, it was inhabited by the following peoples: Curonians, Semgallians, Selonians, Livonians, Latvians, Wends, Lithuanians, Estonians; Oeselians (inhabitants of Saaremaa, who are not distinguishable from the Estonians), and Swedes (mainly on islands) (id. 19-22). Schwartz concluded that these people (except the Swedes and Wends) formed only two branches: Livonians, Estonians, and Oeselians belong to the Finnic branch and Curonians, Semgallians, Selonians, Latvians, and Lithuanians belong to another branch (id. 22). He divided Livonia into 21 landscapes. Here we only describe in more detail those territories ${ }^{3}$ that were inhabited by Livonians (id. $31 \mathrm{ff}$.)

From the western end:

1) The landscape of Curonians (Klaipeda, Liepaja, Ventspils); from the Curonian Lagoon to Embūte (Amboten).

2) The landscape of Semgallians.

3) The landscape of Selonians.

On the other side of the River Daugava:

1) Principality of Jersika. It was ruled by the Russian princes. Mainly Lithuanians lived here.

2) Principality of Koknese. Inhabited by mainly Lithuanians as well, but also by Selonians and (Ascheradian) Livonians of Aizkraukle.

3) The landscape of Asheradian Livonians of Aizkraukle. They were tributary to Vladimir, the Prince of Polotsk. They had no rulers over their own seniors. The centrum of this landscape was in Aizkraukle Castle. No other place is mentioned except the village Remine (maybe Remershof) in old documents.

4) The landscape of Lennewardian Livonians of Lielvārde. They belong to the Principality of Polotsk, but they had their own

3 Schwartz used the term Landschaft in German; for that reason I will use the term landscape instead of territory in the following text. 
seniors who lived in the Lielvārde Castle. Their territory extended on both sides of the River Ogre (Woga, Oger) and reached the village Mālpils (Lemburg) in the North. Remarkable places of the region are Memekülle (according to a note of the editor, i.e. Hupel: Memekülla), now Rembates manor (Ringmundshof), which is united with Lielvārde; Sydegunde (Siggund near Lielvārde); and Sattesele (Suntaži, Sunzel).

5) The landscape of the Ykesküllian ${ }^{4}$ Livonians of Ikšksile. They were tributary to Polotskian Princes too and had their own seniors.

6) The landscape of the Holmian Livonians of Salaspils. Like many other Livonians they also were tributary to Polotskian Princes, but had their own seniors. This landscape has the following remarkable places: Rige (Riga), Hill of St. Nicolaus near the outflow of the River Daugava, and Ropa (Rodenpois, Ropaži). Schwartz rejects some explanations of the name Riga, e.g. Rising, a former brook near Riga, proposed by archiater Johann Bernhard von Fischer, but he thought it plausible that the name of Riga was derived from rige 'a local (Livonian and Estonian) farmhouse type including a drying barn' (id. 45).

7) The landscape of the Toreidian Livonians. They had their own seniors, but they stood under the Polotskians. There are two remarkable places - Toreida (Treiden, Turaida) and Fredeland, a castle in Toreida.

8) The landscape of the Idumean (Ydumäischen) Latvians.

9) The main landscape of the Latvians.

10) The landscape of the Tālava Latvians.

11) The Latvian landscape of Metsepole, i.e. the Metsepole that belongs to Latvia. It is located between the River Salaca and Rūjiena. Although Schwartz does not mention Livonians here it is clear that Livonians lived on the left bank.

12) The Estonian landscape Saccala.

13) The landscape of the Estonians of Saletse (Salaca) on the right bank of the River Salaca.

14) The landscape of Sontagana.

15) The landscape of Uggannien (Hupel: often Ungannien).

16) The Estonian landscape Wyk (Wiik).

17) The Estonian landscape Jerven (Järva)

18) The Estonian landscape Wyren (Viru).

19) The Estonian landscape Harrien (Harju).

20) The Estonian landscape Allentaken (Alutaguse).

21) The Estonian Isles of Saaremaa, Hiiumaa, Muhu, Vormsi etc.

4 On the interpretation and meaning of the name Uexküll see Sutrop (2003). 
As Curonians were not Livonians to Schwartz, there were six Livonian landscapes according to him:

1) The landscape of Asheradian Livonians of Aizkraukle (part of the Asheradians lived together with Lithuanians in the Principality of Koknese).

2) The landscape of Lennewardian Livonians of Lielvārde.

3) The landscape of the Ykesküllian Livonians of Ikšksile.

4) The landscape of the Holmian Livonians of Salaspils.

5) The landscape of the Toreidian Livonians.

6) The Latvian landscape of Metsepole [Livonians].

\section{Discussion and summary}

If we compare them with the division of Jannau (1828, cf. Sutrop 2009: 308) we can see that Jannau divided Livonian territories into nine districts. The coincidences and differences are shown in Table 1. Although Jannau declared that he had followed Schwartz, his division of the Livonian territories is quite different from Schwartz. This table compares the old divisions of Livonia with the modern ones as well.

Table 1 shows the historical division of the territories inhabited by the Livonians. The main difference between Koski on the one side and Schwartz and Jannau on the other side lies in the Daugava group. Koski put all Daugava Livonians together and presented them as a single group. Earlier authors described three or four Livonian areas on this territory. If we take a look on the Gauja Livonians, we can see that Schwartz put them all together, whereas Jannau and Koski divided them into four groups.

Evald Tõnisson has published an interesting map (Figure 1) on the territories of the Finnic tribes in Latvia (Tõnisson 1970). He accepted that there were larger Finnic territories than the known Livonian territories in Latvia in the first millennium and at the beginning of the second millennium. At the same time he did not attribute these territories to the Livonians. According to him Curonians were Finnic, but Coastal Livonians on the northern coast of Courland appeared in the sixteenth century. According to him (Tõnisson 1970) there were four Livonian territories - Daugava, Gauja, Metsepole, and Idumea at the beginning of the second millennium.

To sum up, it is clear that there is no exact consensus on the division and sub-division of the former Livonian territories. Even the question of the Coastal Livonians in Courland - were they an indigenous Livonian tribe or a replaced eastern Livonian tribe remains unsolved. 


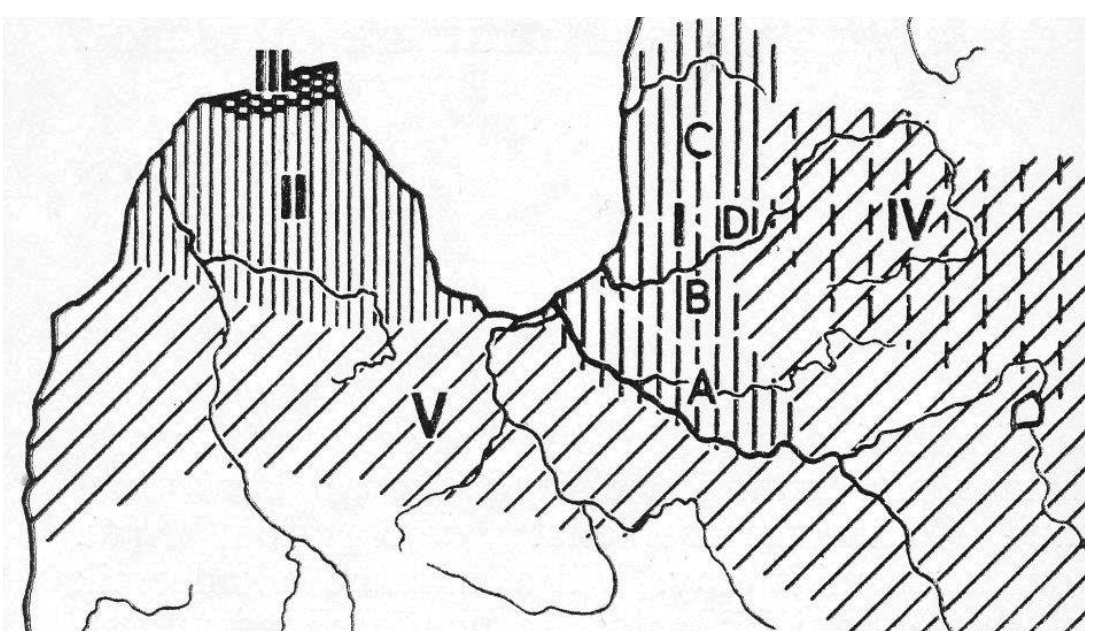

Figure 1. Territories of the Finnic tribes in Latvia after Tõnisson 1970.

I - Livonians at the Eastern coast of the Gulf of Riga at the beginning of the second millennium CE (A - Daugava Livonians, B - Gauja Livonians, C - Metsepole, D - Idumea).

II - Finnic tribes in Courland at $1000 \mathrm{CE}$.

III - Coastal Livonians on the northern coast of Courland in the 16th 20th centuries CE.

IV - Finnic tribes in the central and eastern parts of Northern Latvia ca 6th-7th centuries CE.

$\mathrm{V}-$ Territories of the Baltic tribes. 
Historical Livonian landscapes and tribes 33

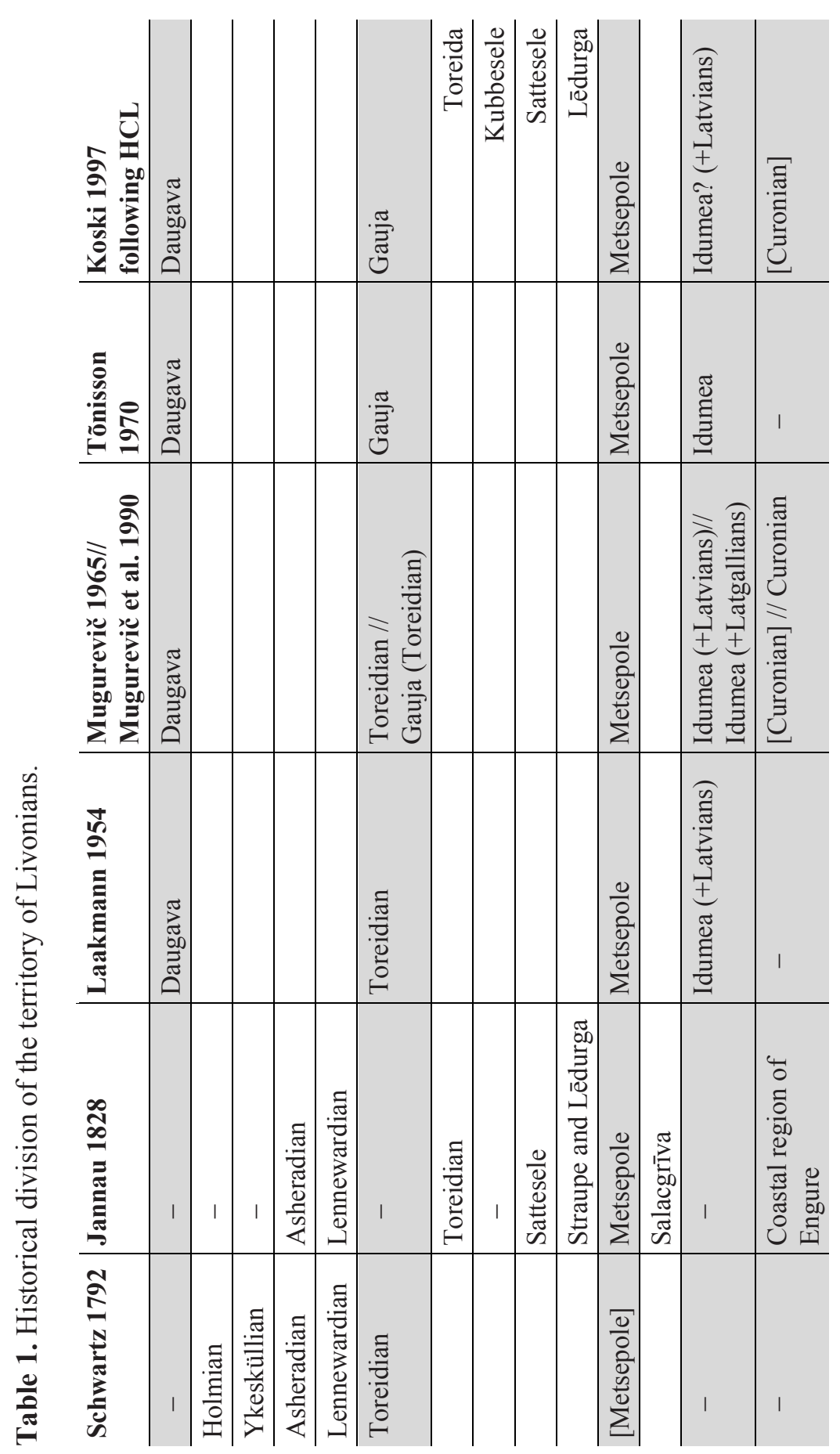


The reason why different authors at different times have divided Livonian territories in different ways lies mainly in their diverse background. The eighteenth-century scholar Schwartz was educated in jurisprudence and he worked primarily with the historical documents. Jannau was active in the nineteenth century, he was educated in theology, but his historical views were based on secondary (philological) sources. The twentieth-century scholar Laakmann was a historian and specialist in historical cartography, Mugurēvičs is and Tõnisson was a historian and archeologist, and Koski was a linguist and philologist. On the one side Koski got similar results with Jannau using philological methods and on the other side, Laakmann, Mugurēvičs, and Tõnisson who all used historical and archeological evidence principally divided eastern Livonians in the same way. Most distinctive from the others was Schwartz who sub-divided the Daugava Livonians into four groups.

The historical division of the territories of the ancient Livonians needs more in-depth explanations. As a next step I plan to thoroughly re-examine the Livonian Chronicle of Henry of Livonia focusing on the division of the Livonian people.

\section{References}

Jannau, Heinrich Georg von (1828) Ueber die Grund- und Ursprache der Ehsten und die Mittel zu einer allgemeinen Schriftsprache zu gelangen. Eine historisch, philologisch-critische Untersuchung, nebst kurzer Zusammenstellung, Vergleichung und Würdigung der Finnischen, Livischen, Reval-Ehstnischen und DorpatEhstnischen Sprache. (Beiträge zur genauern Kenntniß der ehstnischen Sprache,19.) Pernau: beim Herausgeber [Rosenplänter] und Reval: bei Bornwasser.

Koski, Mauno (1997) "Liivimaa”. In Karl Pajusalu and Sullõv Jüvä , eds. Õdagumeresoomõ lõunapiiŕ, 43-59. (Publications of Võro Institute, 1.) Võro: Võro Instituut.

Laakmann, Heinrich (1954) Die Baltischen Lande. (Staats- und Vervaltunggrenzen on Ostmitteleuropa. Historisches kartenwerk, 1.) München: R. Oldenbourg.

Mugurevič, É. S. (1965) Vostočnaja Latvija i sosednie zemli v X-XII vv. Riga: Zinatne.

Mugurevič, É., A. Zarinja, and É. Tynisson (1990) “Livy”. In Finny v Evrope. VI-XV veka. Pribaltijsko-finskie narody istoriko-arxeologiceskie issledovanija. Vyp. 1: Formirovanie pribaltijskix finnov, plemena Finljandii i Jugo-Vostočnoj Pribaltiki, 131-144, 147-151. Moscow.

Schwartz, Johann Christoph [Sine nomine] (1792) "Versuch einer alten Geographie von Liefland, zu besser'm Verstand der alten (liefländischen) Geschichtschreiber. Nebst etlichen Anmerkungen zu dieser Geographie". Neue nordische Miscellaneen. Von August Wilhelm Hupel. Erstes und zweytes Stück, 11-134. Riga: bey 
Johann Friedrich Hartknoch. Available online at $<$ http://www.utlib.ee/ekollekt/eeva/index.php?lang=en\&do=tekst\&tid=3915>. Accessed on 16.01.2014.

Sutrop, Urmas (2003) "Names are more than names: a note about the name Uexküll". Semiotica 147, 1-4, 421-427.

Sutrop, Urmas (2009) "Heinrich von Jannau on the Livonians and Livonian Language in Rosenpänters's Beiträge (1828)”. Linguistica Uralica 45, 4, 307-309.

Sutropss, Urmass (2013) "Par lībiešu Metsepoles novada robežām ziemeḷos senās neatkarības laikos". In R. Blumberga, T. Mekeleinens, and K. Pajusalu, eds. Lībieši. Vešture, valoda un kultura, 133-147. Riga: Līvõ Kultūr sidām.

Sutrop, Urmas and Karl Pajusalu (2009) "Medieval Livonian County Metsepole and the historical and linguistic border between Livonians and Estonians". Linguistica Uralica 45, 4, 253-268.

Tõnisson, Evald (1970) “Muistsed liivlased ja Kuramaa liivlased”. Keel ja Kirjandus $13,8,461-466$.

Turlajs, Jānis, ed. (2012) Latvijas vēstures atlants. 4th ed. Riga: Karšu izdevniecība Jāņa sēta.

Kokkuvõte. Urmas Sutrop: Liivi maastikud Liivimaa ajaloolises geograafias ja liivi hõimude jaotus. Tänapäeval puudub täielik konsensus, kuidas liivlaste territoorium jagunes muinasmaakondadeks ja/või -kihelkondadeks muistse iseseisvuse lõpul 12. sajandil. Lahendamata on isegi küsimus sellest, kas Kuramaa rannaliivlased on muistsete liivlaste või sinna 16. sajandil ümber asunud liivlaste järeltulijad. Käesolevas artiklis vaadeldakse 1792. aastal Johann Christoph Schwartzi anonüümselt ilmunud käsitlust Liivimaa ajaloolisest geograafiast ning võrreldakse seda tollaste ja tänapäevaste arusaamadega. Kokkulepe teadlaste vahel on üldisem idapoolsete liivlaste territoriaalses suurjaotuses: Väina jõe liivlase alad, Koiva jõe liivlaste alad, Metsapoole ja Idumea. Neist viimast peetakse liivlaste ja balti hõimude segaalaks. Samas puudub konsensus nende liivi maakondlike alade edasisest kihelkondlikust jaotusest.

Märksõnad: Johann Christoph Schwartz, ajalooline geograafia, liivi hõimud, Liivimaa

Kubbõvõttõks. Urmas Sutrop:Līvõ mōpālgõd Līvõmō istōrilis geogrāfijs. Tämpõ tuņšlijid äb ūotõ īdmēl̦izt, kui līvlizt terītori vỏl jagdõd muinižiz mōgõniž ja/agā pagāstõdõksks muiniz īžpīlimiz lopāndõksõs 12. āigastsadā àigal. Äb ūo arāntõt, või Kurāmọ līvlizt ātõ muinizt līvlizt tagāntullııid agā 16. àigastsadā āigal sīṇõ länõd līvlizt tagāntullı̣id. Sies kēras um vaņţõltõd 1792. 
āigastõs ulztund Johann Christoph Schwartz tunšlõkst il̉ Līvõmō istōriliz geogrāfij (ulzõtuldsõ se tuņšlõks vỏḷ anonīmi). Siedā um îtõltõd sīeaigizt ja paldīņizt arusōmiztõks. Tunšlijid ātõ dižānist îdmēḷizt mōgõrpūoḷizt līvlizt teritorij jagdõksõs: Vēna joug līvlizt mō, Koiva joug līvlizt mōd, Mõtsāpūol ja Idūmō. Idumō um mō, kus um līvlizt ja baltõd sugūd jelīzt siegāmõl. İdmīel äb ūo, kui mōgõnd jagīzt kīlgõniž. 